\title{
POVERTY AND FAITH AS REFLECTED IN MAJID MAJIDI'S CHILDREN OF HEAVEN
}

\author{
Diyah Fitri Wulandari \\ English Literature Department Sultan Agung Islamic University \\ e-mail: diyahfitri@unissula.ac.id
}

\begin{abstract}
People in the world are facing problem. The problems could be vary, like health, financial, education, poverty etc. In facing the problem, one's should have a personal shield that can protect him/herself from doing bad deeds. Faith is one of the personal shield. Children of Heaven is a film which tells about main characters' problem dealing with poverty. This study aimed at analyzing the main characters' faith in coping problems dealing with poverty. This is a qualitative study. The data in this study were taken from Majid Majidi's Children of heaven. The result of this study found that faith brings the main role in the main character's attitude. Ali, and his family shows how they can cope their problems dealing with poverty and the faith as their personal shield. The manifestation of the faith are shown in character's attitude like patience, obedience to the parents, and honesty.
\end{abstract}

Keywords : Faith, Poverty, Children of Heaven

\section{Abstrak}

Setiap orang di dunia ini memmiliki masalah. Masalah yang dihadapi setiap orang berbedabeda seperti masalah kesehatan, keuangan, pendidikan kemiskinan dan lain-lain. Dalam menghadapi masalah-masalah tersebut, seseorang memelukan pelindung untuk diri sendiri yang dapat menjaganya dari perbuatan tecela. Salah satu pelindung diri tersebut adalah iman. Film Children of Heaven merupakan film yang bercerita tentang iman karakter utama dalam menghadapi masalah hidupnya, yaitu kemiskinan. Penelitian ini bertujuan untuk menganalisis bagaimana iman karakter utama meghadapi masalah dalam hidupnya terutama masalah kemiskinan. Penelitian ini merupakan penelitian kualitatif. Data dalam penelitian ini diambil dari film yang berjudul Children of Heaven jarya Majid Majidi. Hasil penelitian ini menunjukkan bahwa iman memiliki peran yang sangat signifikan pada karakter utama dalam film tersebut. Ali dan keluarganya dapat menyelesaikan masalah-masalah dalam hidupnya terutama yang berhubungan dengan kekurangannya dengan iman dalam diri mereka. Manifestasi iman yang terdapat pada karakter utama dalam film tersebut Antara lain kesabaran, patuh pada orang tua dan kejujuran.

Kata Kunci : Iman, Kemiskinan, Children of Heaven

\section{BACKGROUND OF THE STUDY}

Literary works emerge through the process of author's imagination. Literary works, in the form of short stories, novels, poems and films, are deep responses from the author to the reality of the world he experienced. Authors express ideas and experiences through works that can be enjoyed by the readers. The author, in writing his work, has never been separated from what is experienced in the environment and the journey of his life. Therefore, literature 
generally reflects the social conditions of the people at the time of the author's life and where the author had visited. The author's social conditions which are the main factors in the birth of literary works encourage the presence of conflict. Conflicts that are present are generally inseparable from real phenomena in society, such as poverty.

Poverty refers to the absence of sufficient sustenance to maintain a complete life. This completeness refers to the provision on different levels of human existence, whether it be physical food and shelter or psychological security or political freedom (Beyers, 2014). However, it still has not been defined nor measured yet the sufficient and also the complete. It may refer the standard of prosperous life in one country. So, it may differ one and others.

Poverty is a problem faced in almost all countries around the world. The problem of poverty often leads to the emergence of other problems such as hunger, crime, environmental problems, education, and even the spiritual. People who are under the poverty line tend to be easy to commit crimes under the pretext of being forced. Therefore, people who are under the poverty line should have more bridle power to avoid immoral acts such as stealing, robbing and others.

The number of crimes in poor society tend to be high because the forced and limited circumstances. Besides, people in poverty are usually have low education and knowledge. It is easy to influence them to do bad deeds, crime for example. Hence, faith plays the main role as a basic character foundation for human as religious being.

Faith is known as bridle power against negative behavior. Therefore, strengthening the values of faith is very much needed for children as the next generation of the nation and religion. If someone has strong faith, surely they have good morality. On the contrary, if you have a bad character, your faith is usually weak.

Children of Heaven is a film that raises a spiritual theme. The film tells the story of a child's faith in facing some social problems, especially poverty. As stated by Ebrahimi, Yusoff and Salman (2015), that in Children of Heaven, there is a very valuable moral value and it can be used as moral learning for children. Therefore, this study is aimed to analyze the main character's behavior to cope his problem dealing with poverty in Children of Heaven.

\section{THEORETICAL FRAMEWORK}

Faith in the Qur'an, translated variously. Ar-Raghib al-Ashfahani said that the word "Faith" is only a word on the lips, but the heart and deeds of non-faith or faith are only acts but the heart and speech are not. Faith in terms is interpreted as spoken orally, justifying in the 
heart and practicing in his actions. Abdul Aziz bin Baaz provides an understanding of the term faith, namely, beliefs that penetrate the heart, with confidence, do not mix with doubts, and give an influence on the views of life, behavior and daily actions (Baaz, 2005). Faith is a form of actualization of justification in the heart that is interpreted verbally and proven by deeds (Baaz, 2005). In other words, Faith is to accept everything that the Prophet Muhammad (pbuh) brought, pronounce two sentences of creed, and do worship according to his function. Faith is not only a belief in the truth of a teaching, but faith is actually a teaching as a basis for doing deeds. Al-qur'an stated this because according to the Al-qur'an even though Satan and the angels are true, but believing in angels is called part of the pillars of faith, while the devil is required to disbelieve in him. Faith is not only a strong and firm belief, but faith is something that must be followed by effort and pious charity so that faith and faith grow into a grounded and beneficial force for individuals and for society and the environment and the natural environment.

Faith is the main element in determining one's spirituality. Faith is the booster for a person to improve a clear noble and moral value (syukur, 2003). In other words, Faith is an essential part in a person's character building process. Faith is divided into two dimensions, cognitive and ethic (Sukur, 2003). Cognitive dimension sees faith as a knowledge in relation its proportional truth. As a result it may give enlightenment. The manifestation of faith in cognitive dimension are in the form of clear thought and appreciation. It is needed in building faith for every person in their soul. Through a clear thought, one may easily gain knowledge which later it is appreciated.

Ethical dimension sees faith as a mental attitude which disembogue into action. In this dimension, Faith is not only knowledge and memory but also manifestation. So, Faith can be a main motor in the process of realization of positive behavior and faith alsi can be a restraint for negative one (Syukur, 2003). If faith is wholly actualized, it will be manifested into good deeds.

Thus, good deeds are an element that cannot be separated from faith. Both are bound together. The ups and downs of faith are in accordance with the levels of good deeds that are done. If the good deeds decrease, it indicates that a person's faith is in frivolity, and so does the opposite. Therefore, faith in one's soul should always be nurtured so it is always stable and reaches a perfect level. Perfect faith can be seen from someone's freedom from being shaken. Besides, the birth of a sense equality that rise to solidarity and strong brotherhood for those who believe. From the description above it can be concluded that the value of faith is a highly 
prioritized. The value of faith which is centered on the principle of monotheism then brings the result in the consequences of the birth of equality and brotherhood.

Faith of a people can be seen from their behavior. For example, people with strong faith will have good attitude and behaviour and it is widely known as akhlaqul karimah. The example of good behaviors are obedience to parents, patient and honest.

\section{METHODOLOGY}

This study is a descriptive qualitative. According to Moleong (20017: 06) descriptive research is research that produces descriptive data in the form of written and oral words from people and observed behavior. Based on this explanation, this study aims to describe the values of faith contained in Film Children of Heaven. The data in this study is the film Children of Heaven by Majid Majidi which was published in 1997 and released in Indonesia in 2000. The data of this study are in the form of sentences in the form of dialogues, monologues and narratives relating to the values of faith. The analysis is done descriptively. It is taken from the subtitles of the movie. So the data used is the English subtitles.

\section{FINDING AND DISCUSSION}

\section{Children of Heaven Film}

Children of Heaven is a film directed by Majid Majidi. It was first published in 1997 with 89 minutes length. The setting took place in Iran, portrayed the condition of lower people in Iran. It was nominated as the Best Film in 1998.

Children of Heaven tells the struggle of the main characters' struggle in facing their socio economic problem. Ali Mandegar, and his sister, Zahra are brother and sisters of a poor family. They live in a Teheran, Iran. Living in a poor family, Ali and Zahra facing their days in patience but they both are enthusiastic in studying at school. One day, Ali's mother asked him to go to the grocery and drop at the shoe soles to take Zahra's shoes.

At the grocery, Ali was busy picking the potatos and he did not realize that there was a scavenger taking some unused stuff in the stall. Zahra's shoes was unintentionally taken. Ali was so upset knowing that he lose his sister's shoes. He was trying to search for them, but he found nothing. He was afraid of disappointing his sisters and also he did not want to trouble his parents. Arriving home, Ali did not tell Zahra what had happened to him and the shoes incident. Until Zahra asked him whether her shoes had been repaired. Finally Ali told Zahra if he lost her shoes, and asked her not to tell their parents about the case. Zahra seemed 
disappointed. All of a sudden, Ali proposed a solution, While they were trying to look for the shoes, Zahra could use his shoes since she went to school in the morning, and they would meet after zahra's class to change the use of shoes. It seemed hard, but they agree. Every day after school, Zahra ran to meet Ali and change the shoes, and Ali did the same, running fast to get to school at scheduled time. It is, unintentionally, train Ali to have a good running skill.

One day, there was a running competition, Ali tried to register himself just for seeing that the third winner will get some price, money and a pair of shoes. After the long wait and selection, he was one of the representatives from his school.

Thae day came. Ali and her friends went to the venue to compete with others runners. Ali started the game well. During the game, He was thinking of getting the third place as his purposed to bring the shoes back to his sister, Zahra. In last minutes, Ali led the game, Ali did his best, he won the first winner. Unfortunately, He did not really happy for his main reason was to sit in third winner. All the people were happy but Ali was not. He cried. He failed to bring the shoes for his sister.

In another place, Ali's father just got some more money. He passed a shoes shop. He dropped and He bought two pairs of shoes, for his children, Ali and Zahra.

\section{Faith as reflected towards the main characters in Children of Heaven Movie}

Faith may be seen through the attitude of someone in their daily life. in the film, the behavior as manifestation of someone's strong faith are obedience, patience and honesty.

Obedience here is specifically the obedience of children to parents. The example of obedience is shown by both Zahra and Ali as the main characters.

Zahra is whole heartedly willing to help her mother to look after her younger. She also does the house works and taking her mother job since she is sick, like washing the clothes, cooking. It is seen in the following dialogue:

Mother: "Zahra has done the house works today."

Father: "A good kid and now please take me a cup of tea, Zahra.

Zahra : "Okay. Here you are..."

Father: "Wow... what a fresh tea, is it. Where is the sugar"

Zahra : "Here, there is much sugar in front of you father; I don't need to take it from the kitchen."

Father: "No Zahra. This sugar isn't ours, it belongs to the mosque."

Zahra : "I am so sorry."

Father: "Ali, tomorrow you must join me to find the customer to use our service."

Ali : "Okay father, I will accompany you." 
The above data shows that the father is happy because his daughter obeys their mother and sincerely help her mother. Zahra understand her family condition. So her father is proud of her. The other attitude shown by Ali as quoted above is that he is willing to help his father working as a gardener. It is firstly hard to find a customer. They go to the town and knock door to door if there is a people who will take their service to take care of the garden. For their perservence, diligent and hard work, they both finally find a customer and unexpectedly the customer agree to have them for a regular maintenance service. This point shows that Ali, as son, voluntarily help his old father working to make living for the family.

Obedience to parents is one of the manifestation of faith in a people. A child who obey their parents, he realizes that their parents' approval is God's blessing. Besides obedience, the manifestation of faith in one's behavior is honesty. Being honest means that he or she realize that every time and everywhere, Allah always see what they do. So, he must be honest in everything to other people and for their selves. In the movie, it is shown below:

Father: "Wow... what a fresh tea, is it. Where is the sugar"

Zahr : "Here, there is much sugar in front of you

Father:"I don't need to take it from the kitchen."

Father: "No Zahra. This sugar isn't ours, it belongs to the mosque."

Zahra : "I am so sorry."

Zahra wants to take the sugar which belong to the mosque to make a cup of tea for the family. However, her father prohibit it by telling that the sugar does not belong to them. Zahra listen to her father. This short story tells that honesty should be rooted as a basic character of a people. In the lowest place, Zahra's father still keeps to tell his children to be honest. People will never know nor realize that they take the sugar. Or probably people will give them some, but the family choose to stay in faith, to be honest.

The above quotation also tells a trusteeship. The society give trust Ali's family to keep the sugar for the mosque, and the family keep the trusteeship. And take it as their obligation. Ali and Zahra obey their parents, the command and also the attitude. Their parents shows an extraordinary lesson for them how to behave as a true Muslim, to be honest and trusted. Trusted as they are responsible to take care of the sugar belong to mosque. People give them trust, and they are responsible for it.

People in faith of course they are patient. When they face the hardest days in their life, they face problems like relationship or even financial problems. They stay in patience. The portrait of patient is also seen in the film. 
Zahra: Ali, have you taken my shoes?

Ali : Mother told me that you should strip the potatoes after take care the baby.

Zahra: But, have you taken my shoes? I want to see it.

Ali : There isn't. It lost ...

Zahra: Are you kidding?

Ali : I am serious. It lost when I was in the shop.

Zahra: Have you tried to look for it?

Ali : Yes, I will try to look for it again. But please, don't tell it to mother.

When he faced a problem, one of which was when Ali loss Zahra's shoes. In the midst of financial difficulties experienced by his family, and the poor health condition of his mother, Ali and Zahra choose to remain patient with the conditions they experienced.

She cannot ask her father to get the new ones. It does not become an obstacle for both of them to always survive in life and fight for their achievements.

The portrait of patient behavior was pointed out by Zahra when she learned that her shoes being repaired were missing. Zahra was patient even though he was disappointed. Zahra was not angry but she held back. Patience is one manifestation of the attitude of faith. Because the real faith is to believe in every event there is wisdom with him.

Here is another example of patience reflected in the film Children of Heaven. Ali volunteered to help Zahra to bring her shoes to repair in shoe repair. When Ali was shopping at the market, he put Zahra's shoes on the seller's shelf. But unlucky, there were scavenger who took items in the shop and accidentally he took Zahra's shoes. Because of the loss, Zahra and Ali try to solve their own problem. And finally they decide a solution. They are agreed to use Ali's shoes, Zahra will use the shoes in the morning since she goes to school in the morning, while Ali will use it after Zahra finishes studying as Ali start the class at noon. This situation is not easy, it requires Ali and Zahra always have to hurry so that Ali will not late for school.

Zahra: How could I go to school without those shoes tomorrow?

Ali : You can wear your sandal.

Zahra: How dare you! You lost those shoes. I must inform it to father!

Ali : No! They don't have money. He will punish us.

Zahra: What should I do?

Ali : You can wear my shoes.

The attitude shown by Ali and Zahra was a very good decision. A very commendable and touching action. This was done because they both did not want their parents to be burdened with this problem. They both show sincerity to accept everything, whether it is good or bad. 


\section{CONCLUSION}

There are a lot of things can be learned from The film "Children of Heaven". This study shows that faith is the main role to build the highest human character. It is concluded that the main characters of the film entitled Children of Heaven shows faith is the fundamental point in human characters. The main characters, Ali and his family, are able to cope and solve their problems especially dealing with their difficulties in poverty by having strong faith that manifested into some attitude like obedience to parents, honest and patient.

\section{REFERENCES}

Abdul Aziz bin Baaz. 2005. Fatwa-Fatwa Terkini Jilid 3, Jakarta: Pustaka Darul Haq.

Ar- Raghib al- Ashfahani. 2007. Cara Cerdas Hafal Al-Qur'an. Solo: Aqwam.

Beyers, J., 2014. 'The effect of religion on poverty', HTS Teologiese Studies/ Theological Studies 70(1), Art. \#2614, 8 pages. http:// dx.doi.org/10.4102/hts. v70i1.2614

Moleong, Lexy J, Prof. DR. MA. 2007. Metodelogi Penelitian Kualitatif. Bandung: PT Remaja Rosda KaryaNurgiyantoro.

Mustakim Hidayatul. 2014. “Representasi Nilai Spiritual Dalam Novel Dzikir Dan Pikirkarya Reza Nurul Fajri”. NOSI.2. P.155-165.2014.

Semi. 1993. Metode Penelitian Sastra.Bandung: Angkasa.

Syukur, Amin. 2003. Tasawuf Kontekstual, Solusi Problem Manusia Modern. Semarang: Pustaka Pelajar.

Wellek, Rene dan Austin, Werren. 1990. Teori Kesusastraan. Jakarta: Gramedia. 